\title{
Original
}

\section{Relation of Inorganic Phosphate Concentration to Buffering Capacity in Whole Mouth Resting Saliva}

\author{
安静唾液における無機燐酸塩濃度と緩衝能との関連性
}

\author{
Itsuo UEDA* \\ 上田五 男*
}

Received September 22, 1986 : Accepted December 1, 1986

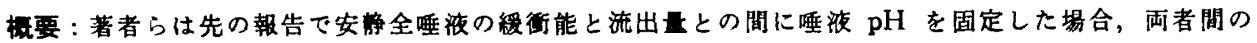
偏相関関係に統計学的有意な負の相関性のあることを示した（口腔街生会誌，34；193，1984.）。をこ

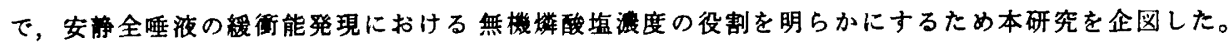

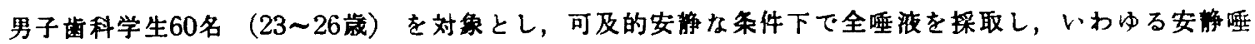

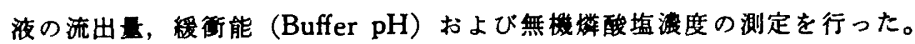

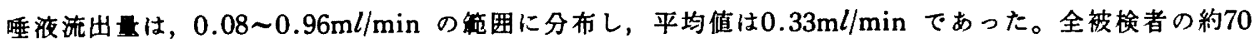
\%の流出量が $0.1 \sim 0.39 \mathrm{~m} l / \mathrm{min}$ の崭囲に含まれた。

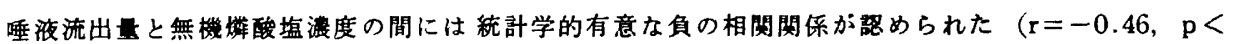
0.001)。しかし，唾液流出と緩衙能值との間には一定の関倸はみられなかった。

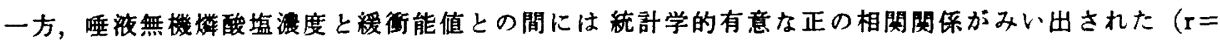
$0.33, \mathrm{p}<0.01$ )。

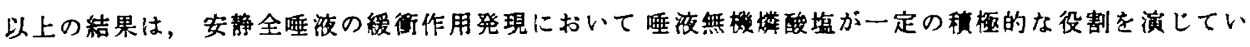
ることを强く示唆している。
\end{abstract}
Koy words: Resting whole saliva, Buffer capacity, Flow rate, Inorganic phosphate con- centration

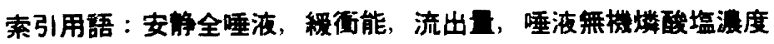

\section{Introduction}

The significance of the protective action of saliva from decrease in the plaque $\mathrm{pH}$ after glucose ingestion has been reported by Stephan ${ }^{1)}$ and others ${ }^{2,3)}$, and they also pointed out its protective effect against dental caries.

It is generally believed that the best established relationship between salivary factors and dental caries is the buffering action of salivat). The role of bicarbonate in the buffering capacity of stimulated whole saliva is well known ${ }^{5-8)}$. However, there are relatively few reports on the buffer effect of the so-called

* Department of Preventive Dentistry, School of Dentistry. Higashi Nippon Gakuen University (Chief: Prof. Nobuyoshi ITO)

* 東日本学園大学蔽学部口腔衛生学教室 (主任: 井藤信義教授) 
resting whole saliva.

In the present study, we have examined the relationship between the buffer capacity and inorganic phosphate concentration in the resting whole saliva, and have also investigated the possible contribution of the latter to the buffering capacity of whole saliva.

\section{Materials and Methods}

Resting whole saliva samples were collected in the so-called resting state with as little movement as possible for fifteen min by the spitting method ${ }^{(1)}$ from 60 healthy, unmedicated male dental students between the ages of 23 and 26 years in a quiet room. The collection time was between 10 a.m. and 11 a.m., at least two hr after a meal. The subjects were made to rinse once with $10 \mathrm{~m} l$ of distilled water, and then to close the lips with the heads tilted down slightly. The accumulated saliva in the floor of the mouth was swallowed, after which the fresh saliva flowing naturally into the mouth was spit into a graduated test tube fitted with a funnel which was held near the mouth. The flow rate was recorded as $\mathrm{m} l$ per $\min$. The measurement of buffering capacity of whole saliva was undertaken with the buffer $\mathrm{pH}$ method ${ }^{10}$ ) in which $0.3 \mathrm{ml}$ of $0.1 \mathrm{~N}$ lactic acid was added to every $2 \mathrm{~m} l$ of the tested saliva and after a through mixing the solution's $\mathrm{pH}$ was measured with a $\mathrm{pH}$ electrode. The coefficient of correlation( $r$ ) between the buffer $\mathrm{pH}$ method and the Ericsson method ${ }^{11)}$ was 0.97 .

The concentration of inorganic phosphate in saliva was determined by the method of Bartlett ${ }^{12)}$. The samples of saliva were centrifuged at 10,000 r.p.m. for 20 minutes and the proteins were removed by precipitation with cold 10 per cent TCA followed by Millipore filtration.

All summarized results are given as arithmetic means with inter-individual standard deviations. The correlation coefficients were calculated with Peasson's formula for product-moment correlation coefficients.

\section{Results}

Table 1 lists the mean values of flow rate, buffering capacity, and inorganic phosphate concentration in the resting whole saliva. The distribution of the flow rates of saliva is given in Fig. 1. The values were in the range of $0.08-0.96 \mathrm{ml} / \mathrm{min}$ with a mean value of $0.33 \mathrm{ml} / \mathrm{min}$. The distribution of the results of buffering capacity of saliva is shown in Fig. 2. The buffer effect (buffer $\mathrm{pH}$ ), expressed as final $\mathrm{pH}$, gives a mean value of $\mathrm{pH} 4.0$ with a range of $\mathrm{pH} 3.35-5.01$. Fig. 3 shows the distribution of inorganic phosphate concentrations in saliva. The concentra-

Table 1 Mean values of flow rate, buffer capacity and inorganic phosphate concentration in resting whole saliva

\begin{tabular}{ll}
\hline & Mean $\pm \mathrm{SD}$ \\
\hline Flow rate, $\mathrm{m} l / \mathrm{min}$ & $0.33 \pm 0.17$ \\
Buffer capacity, pH & $4.00 \pm 0.13$ \\
Inorganic phosphate, $\mathrm{mg} / \mathrm{d} l$ & $16.6 \pm 5.6$ \\
\hline
\end{tabular}

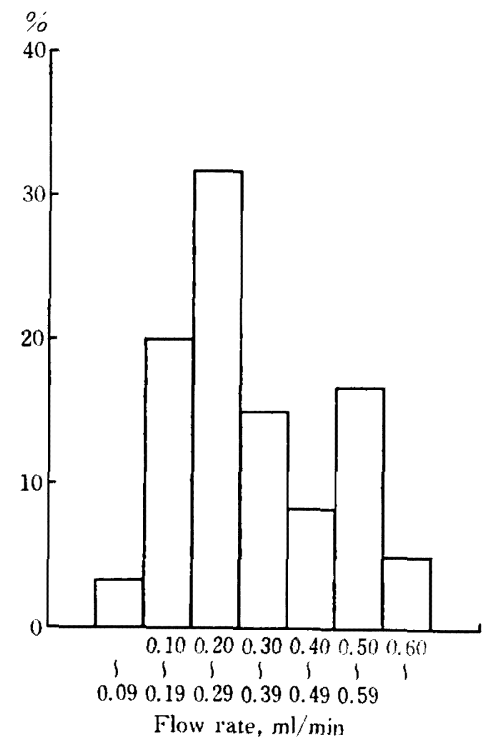

Fig. 1 Frequency distribution of the flow rates in resting whole saliva. 


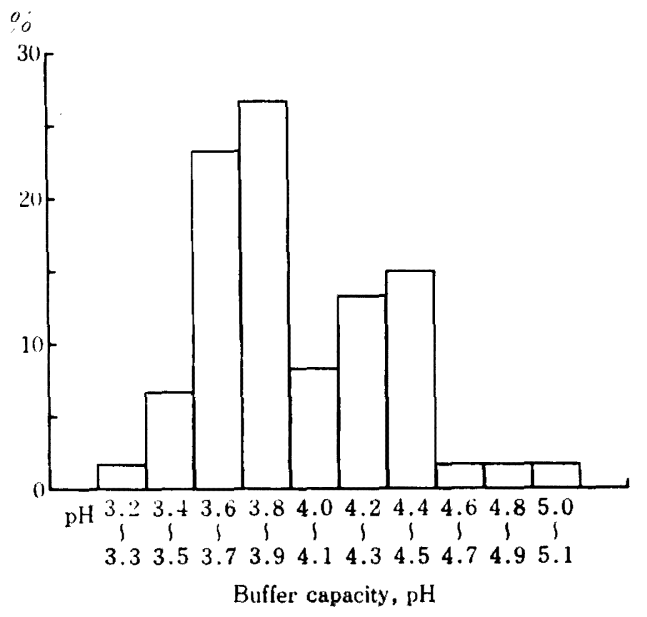

Fig. 2 Frequency distribution of the buffer capacity values in resting whole saliva.

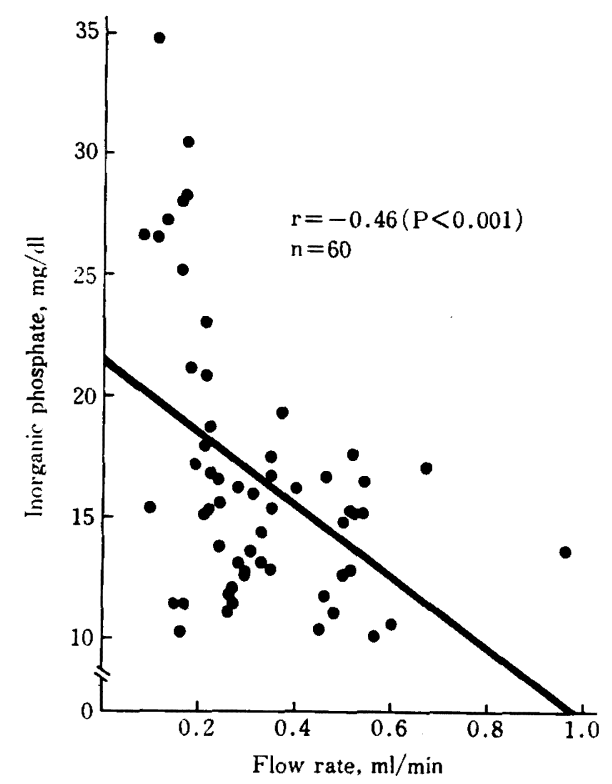

Fig. 4 The relation between the flow rate and inorganic phosphate concentration of resting whole saliva.

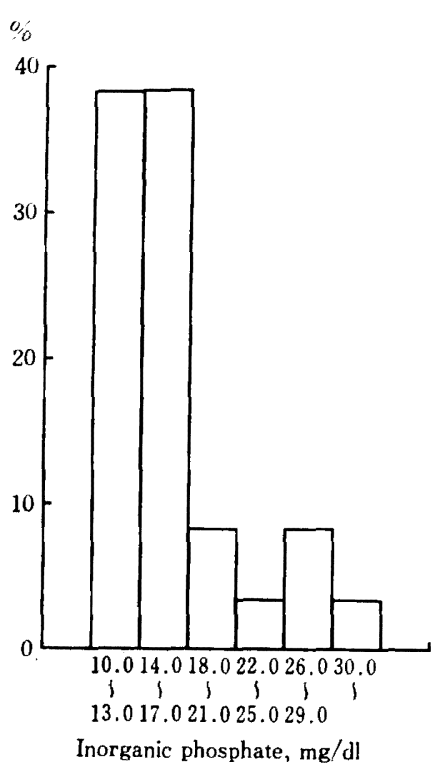

Fig. 3 Frequency distribution of the inorganic phosphate concentrations in resting whole saliva.

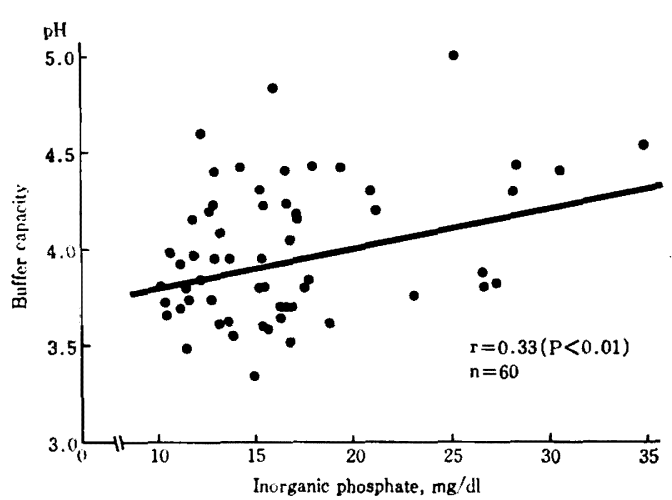

Fig. 5 The relation between the inorganic phosphate concentration and buffer capacity of resting whole saliva.

tions varied from 10.1 to $34.9 \mathrm{mg} / \mathrm{d} l$ and the average value was $16.6 \mathrm{mg} / \mathrm{d} l(1.75 \mathrm{mM}) .80 \%$ of the total was within $10.0-17 \mathrm{mg} / \mathrm{d} l$.

Fig. 4 shows the relationship between the flow rate and inorganic phosphate concentration in resting whole saliva. A statistically significant inverse correlation was found between the two.

Fig. 5 shows the relationship between the buffering capacity and phosphate concentration in the whole saliva. The direct correlationship between the two was statistically significant : the higher the former, the higher the latter and vice versa. 
There was not a uniform relationship between the buffer capacity and flow rate in the resting whole saliva.

\section{Discussion}

The flow rate of resting whole saliva in this study is in good agreement with the findings of Becks and $\mathrm{W}$ ainwright ${ }^{13)}$ in the age groups of $20-29$ years. $70 \%$ of the total samples was in the range of $0.1-$ $0.39 \mathrm{~m} l / \mathrm{min}$.

The present study showed a significant inverse relationship between the flow rate and inorganic phosphate concentration in resting whole saliva. Some investigators ${ }^{14-16)}$ reported that the phosphate concentration was inversely related to the flow rate in human parotid saliva. Likewise, whole resting saliva contained a more inorganic phosphate than stimulated saliva ${ }^{17,18)}$

Dawes $\left.{ }^{14}\right)$ showed that at flow rates of $0.25,0.50$, and $1.00 \mathrm{~m} l / \mathrm{min}$ the mean phosphate concentrations of parotid saliva were $4.38,3.61$, and $3.10 \mathrm{mM}$, respectively. Our previous data ${ }^{17}$ ) showed a significant correlationship $(r=-0.58 ; p<0.01)$ between the flow rate and inorganic phosphate concentration in centrifuged resting whole saliva.

The present study showed a significant direct correlation between the buffer capacity and inorganic phosphate concentration in the resting saliva. This clearly shows that the concentration of inorganic phosphate contributes partially to the buffering action of resting whole saliva. Our previous investigation ${ }^{101}$ has already shown that in resting whole saliva there is a significant inverse relation between the buffer capacity and flow rate in the partial correlational analysis if the $\mathrm{pH}$ of saliva is fixed to remove its effect. This strongly suggests an essential role of the phosphate buffer system in the buffering action of resting whole saliva.

The importance of salivary buffering capacity as endogenous resistant factor against dental caries has already been confirmed ${ }^{8,4)}$. Wah Leung) ${ }^{\text {s) }}$ showed that bicarbonate was the most important buffer in saliva, and he suggested that the phosphate and proteins make up the remaining buffering activity, particularly at lower $\mathrm{pH}$ ranges than 7.2 to 6.8 . For the buffer capacity in resting whole saliva Lilienthal ${ }^{8)}$ showed that the proportion of total buffering power which is contributed by the bicarbonate system varied from 30 to 85 per cent, suggesting that the only other buffer system having appreciable activity is probably phosphate.

On the other hand, Shannon et al. ${ }^{19)}$ reported that the concentrations of inorganic phosphate were higher in caries resistant than in caries susceptible individuals.

It seems that the salivary phosphate, especially in the resting saliva, would act as a caries resistant factor to an extent varying with its salivary content.

Finally, it would be of interest to investigate the influence of phosphate concentration and buffering capacity in the resting saliva on the plaque $\mathrm{pH}$ changes which are related to the caries process.

\section{References}

1) Stephan, R. M.: Intra-oral hydrogen-ion concentrations associated with dental caries activity, J. Dent. Res., 23 ; 257, 1944.

2) Englander, H. R., Shklair, L. L. and Fosdick, L. S. : The effects of saliva on the $\mathrm{pH}$ and lactate concentration in dental plaque, J. Dent. Res., 38 ; 848, 1959.

3) Mandel, I. D.: Relation of saliva and pla- que to caries, J. Dent. Res., 53 ; 246, 1974.

4) Ericsson, Y.: Recent advances in dental caries research. Biochemistry, salivary and food factors in dental caries development, Int. Dent, J., 12 ; 476, 1962.

5) Wah Leung, S.: A demonstration of the importance of bicarbonate as a salivary buffer, J. Dent. Res., 30 ; 403, 1951.

6) Lilienthal, B.: An analysis of the buffer systems in saliva, J. Dent. Res., $34 ; 516$, 
1955.

7) Dreizen, S., Reed, A. I., Niedermeier, W. and Spies, T. D.: Sodium and Potassium as constituents of human salivary buffers, J. Dent. Res., 32 ; 497, 1953.

8) Sellman, S.: The buffer value of saliva and its relation to dental caries, Acta Odont. Scand., $8 ; 244,1950$.

9) Navazesh, M. and Christensen, C. M. : A comparison of whole mouth resting and stimulated salivary measurement procedures, J. Dent. Res., 61 ; 1158, 1982.

10) Ueda, I., Anbe, H. and Nakao, S.: A rapid clinical evaluation of salivary buffer $\mathrm{pH}$, J. Dent. Health, 34; 193, 1984.

11) Ericsson, Y.: Clinical investigations of the salivary buffering action, Acta Odont. Scand., $17 ; 131,1959$.

12) Bartlett, G. R. : Phosphorus assay in column chromatography, J. Biol. Chem., 234 ; 446, 1959.

13) Becks, H. and Wainwright, W. W.: Human saliva, XIII. Rate of flow of resing saliva of health individuals, J. Dent. Res., 22 ; 391, 1943.

14) Dawes, C.: The effects of flow rate and duration of stimulation on the concentrations of protein and the main electrolytes in human parotid saliva, Archs Oral Biol., $14 ; 277$, 1969.

15) Kreusser, W., Heidland, A., Hennemann, H., Wigand, M. E. and Knauf, H. : Monoand divalent eletrolyte patterns, $\mathrm{PCO}_{2}$ and $\mathrm{pH}$ in relation to flow rate in normal human parotid saliva, Europ. J. clin. Invest., 2 ; 398, 1972.

16) Blomfield, J., Rush, A. R. and Allars, H. M. : Interrelationships between flow rate, amylase, calcium, sodium, potassium and inorganic phosphate in stimulated human parotid saliva, Archs Oral Biol., $21 ; 645,1976$.

17) Anbe, H., Ueda, I., Nakao, S., Azewaki, Y. and Himi, K. : Fluoride, calcium, and phosphorus contents of human saliva, Bull. Josai Dent. Univ., $10 ; 383,1981$.

18) White, J. and Bunting, R. W.: A comparison of the chemical composition of stimulated and resting saliva of caries-free and cariessusceptible children, Am. J. Physiol., 117 ; $529,1936$.

19) Shannon, I. L., Lsbell, G. M., Gibson, W. A. and O'leary, T. J.: Salivary inorganic phosphate concentrations as related to dental caries experience, U.S.A.F., School of Aerospace, Report 67-71, 1962. 